\title{
Supplementation with Japanese bunching onion (Allium fistulosum L.) expressing a single alien chromosome from shallot increases the antioxidant activity of Kamaboko fish jelly paste in vitro
}

\author{
KAZUKI HARADA ${ }^{1}$, RITSUKO WADA ${ }^{2}$, SHIGENORI YAGUCHI ${ }^{3}$, TOSHIMICHI MAEDA ${ }^{1}$, RIE DATE $^{2}$, \\ TAKUSHI TOKUNAGA ${ }^{1}$, KIMIKO KAZUMURA ${ }^{4}$, KAZUKO SHIMADA ${ }^{5}$, MISATO MATSUMOTO ${ }^{6}$, \\ TADAYUKI WAKO $^{3}$, NAOKI YAMAUCHI ${ }^{6}$ and MASAYOSHI SHIGYO ${ }^{6}$ \\ ${ }^{1}$ Course of Resource Management and Food Science, Graduate School of Fisheries Science and \\ ${ }^{2}$ Laboratory of Marine Food Processing and Safety, Department of Food Science and Technology, \\ National Fisheries University, Independent Administrative Institution, The Ministry of Agriculture, \\ Forestry and Fisheries of Japan, Yamaguchi $759-6595 ;{ }^{3}$ NARO Institute of Vegetable and Tea Science (NIVTS), National \\ Agriculture and Food Research Organization, Mie 514-2392; ${ }^{4}$ Central Research Laboratory, \\ Hamamatsu Photonics K.K., Shizuoka 434-8601; ${ }^{5}$ Faculty of Nursing and Human Nutrition, \\ Yamaguchi Prefectural University, Yamaguchi 753-8502; ${ }^{6}$ Faculty of Agriculture, \\ Yamaguchi University, Yamaguchi 753-8515, Japan
}

Received January 11, 2013; Accepted February 22, 2013

DOI: $10.3892 / b r .2013 .77$

\begin{abstract}
Kamaboko is a traditional type of processed seafood made from fish jelly paste that is unique to Japan. We supplemented Kamaboko with Japanese bunching onion (Allium fistulosum L.) with an alien monosome from shallot (Allium cepa L. Aggregatum group) and we measured in vitro the oxygen radical absorbance capacity (ORAC) value, an index of antioxidant activity. We also evaluated the results of sensory testing. The ORAC value of plain Kamaboko was $166 \pm 14 \mu \mathrm{mol}$ trolox equivalent (TE)/100 $\mathrm{g}$ fresh weight $(\mathrm{FW})$. The values of the edible Alliaceae powder, i.e., Japanese bunching onion (JBO, genome $F F, 2 n=2 x=16$ ) and the alien addition line of JBO carrying the $6 \mathrm{~A}$ chromosome from shallot $(\mathrm{FF}+6 \mathrm{~A}, 2 \mathrm{n}=2 \mathrm{x}+1=17)$, were $6,659 \pm 238$ and $14,096 \pm 635 \mu \mathrm{mol}$ TE/100 g dry weight (DW). We hypothesized that the $6 \mathrm{~A}$ chromosome encoded the enhancement of polyphenol production. Subsequently, we created Kamaboko containing $4.8 \%$ JBO powder or $4.8 \%$ $\mathrm{FF}+6 \mathrm{~A}$ powder. The ORAC value of each modified Kamaboko
\end{abstract}

Correspondence to: Dr Kazuki Harada, Course of Resource Management and Food Science, Graduate School of Fisheries Science, National Fisheries University, Independent Administrative Institution, The Ministry of Agriculture, Forestry and Fisheries of Japan, 2-7-1 Nagata-Honmachi, Shimonoseki-shi, Yamaguchi 759-6595, Japan

E-mail: kazuki@fish-u.ac.jp

Key words: antioxidant activity, fish jelly paste, Japanese bunching onion, shallot, alien addition line, chromosome engineering product was increased to $376 \pm 24 \mu \mathrm{mol} \mathrm{TE} / 100 \mathrm{~g} \mathrm{FW}$ for the JBO powder and to $460 \pm 16 \mu \mathrm{mol} \mathrm{TE} / 100 \mathrm{~g} \mathrm{FW}$ for the FF+6A powder, respectively. We next created Kamaboko containing $9.0 \% \mathrm{JBO}$ powder or $9.0 \% \mathrm{FF}+6 \mathrm{~A}$ powder and the ORAC values of the respective modified Kamaboko products was increased to $671 \pm 16$ and $740 \pm 21 \mu \mathrm{mol} \mathrm{TE} / 100 \mathrm{~g} \mathrm{FW}$, i.e., 4.1- and 4.5-times the value of plain Kamaboko. Consequently, taking into consideration the sensory evaluation regarding taste and appearance as well, the use of Kamaboko supplemented with $4.8 \% \mathrm{FF}+6 \mathrm{~A}$ powder is recommended.

\section{Introduction}

Kamaboko is a traditional type of seafood made from fish jelly paste that is unique to Japan. Imitation crab meat made from Kamaboko fish jelly paste has become commercially available worldwide. Minced fish (surimi) is the main ingredient of Kamaboko. Surimi and Kamaboko have been extensively investigated from the viewpoint of the production method and physical properties (1-6). However, their health benefits have been investigated to a limited extent $(7,8)$.

Plants generally possess notable antioxidant activities due to their content of various polyphenols, i.e., flavonoids (9). However, the Japanese bunching onion (JBO, Allium fistulosum L.), which is a Japanese favorite food item, has a low polyphenol content (10). By contrast, the edible part of the shallot (Allium cepa L. Aggregatum group) contains a high amount of flavonoids $(11,12)$. Shigyo et al added a single alien chromosome from the shallot to the JBO using chromosome engineering, significantly increasing the polyphenol content of the JBO $(10,13-15)$. 
Furthermore, we have already confirmed the antioxidant activities of fish sauces and gelatin gel foods made from unutilized fish parts, giant jellyfish and buckwheat protein in vitro, using chemiluminescence, electron spin resonance (ESR), apurinic/apyrimidinic DNA site determination, oxygen radical absorbance capacity (ORAC) and hydroxyl radical averting capacity (H-ORAC) measurement (16-20).

Subsequently, we created Kamaboko fish jelly paste supplemented with JBO with a shallot alien monosome and the in vitro antioxidant activity, i.e., ORAC value, was measured. The results of sensory testing were also evaluated and the new type of Kamaboko is recommended due to its antioxidant properties.

\section{Materials and methods}

Samples. The plant material used as control was the JBO (Allium fistulosum L., 'Kujyo-hoso', 2n=2x=16, FF). Control plants were harvested between April, 2005 and March, 2006 or January, 2010 from a farm field of the Faculty of Agriculture, Yamaguchi University. The sample plant had an alien addition line of JBO carrying the 6A chromosome from the shallot (Allium cepa L. Aggregatum group) $(2 \mathrm{n}=2 \mathrm{x}+1=17, \mathrm{FF}+6 \mathrm{~A})$. Sample and control plants were harvested at the same time. The leaf blades of these plants were made into a powder by freeze-drying at the Faculty of Agriculture, Yamaguchi University. Two types of Kamaboko were produced by Sanyo Foods Industry, Co., Ltd. (Yamaguchi, Japan). Control Kamaboko was made from Alaska pollock surimi, starch, egg white, $\mathrm{NaCl}$, crab extract, sugar, vegetable oil, amino acids, essences and water by heating at $90^{\circ} \mathrm{C}$ for $10 \mathrm{~min}$ in a water bath. Sample Kamaboko was created from control Kamaboko by the addition of the plant sample powders.

Chemicals. 2,2'-Azobis (2-amidinopropane) dihydrochloride $(\mathrm{AAPH})$, dipotassium hydrogen phosphate $\left(\mathrm{K}_{2} \mathrm{HPO}_{4}\right)$, and ethyl alcohol (99.5\%) were obtained from Wako Pure Chemical Industries, Ltd. (Osaka, Japan). Potassium dihydrogen phosphate $\left(\mathrm{KH}_{2} \mathrm{PO}_{4}\right)$ was obtained from Kanto Chemical Co., Inc. (Tokyo, Japan). Fluorescein sodium salt was purchased from Sigma-Aldrich Japan (Tokyo, Japan) and 6-hydroxy-2,5,7,8-tetramethylchroman-2-carboxylic acid (trolox) was purchased from Tokyo Kasei Kogyo Co., Ltd. (Tokyo, Japan).

Sample preparation. Two grams from each sample were measured by the ORAC method following homogenization with $20 \mathrm{ml} 70 \%$ ethyl alcohol, using a polytron PT2100 (Kinematica AG, Lucerne, Switzerland). The samples were as follows: raw control JBO (FF), raw JBO with added 6A, dried powder of JBO, dried powder of JBO with added 6A, control Kamaboko and Kamaboko supplemented with sample plant powder. The sample solutions were centrifuged at 2,580 x g for $10 \mathrm{~min}$ and the supernatants were frozen as the stock sample solutions.

Preparation of hydrophilic-ORAC (H-ORAC) reaction solution. H-ORAC reaction solution was prepared as previously described $(19,21)$. Phosphate buffer was used as the assay (control) buffer and was prepared by combining $75 \mathrm{mM}$ $\mathrm{K}_{2} \mathrm{HPO}_{4}$ and $75 \mathrm{mM} \mathrm{KH}_{2} \mathrm{PO}_{4}$ to a final volume of $75 \mu \mathrm{mol}$
$(\mathrm{pH}$ 7.0). AAPH reagent was dissolved in the buffer at a concentration of $31.7 \mathrm{mM}$. Fluorescein working solution was prepared at a concentration of $94.4 \mathrm{nM}$ by dissolving fluorescein sodium salt in the buffer. Trolox standard solutions were prepared at concentrations of $100,50,25,12.5$ and $6.25 \mu \mathrm{M}$ by dissolving trolox in the buffer.

Measurement of $\mathrm{H}$-ORAC. The ORAC value was obtained by measuring the elimination capacity of peroxyl radicals generated by the AAPH reagent and by measuring the time lapse degradation of fluorescein (i.e., the rate of decrease in the intensity of fluorescence) $(19,22)$. The ORAC assay was performed using a 96-well Mithras LB940 multimode microplate reader (Berthold Technologies GmbH \& Co. KG, Bad Wildbad, Germany) as previously described (19,23). In brief, $20 \mu \mathrm{l}$ of each sample buffer (obtained by appropriate dilution with the assay buffer) and various concentrations of trolox standard solution (for concentration of a standard curve) or blank buffer (as a control) were placed in the individual wells of a 96-well transparent microplate (Sanplatec Corp., Osaka, Japan). Fluorescein working solution $(200 \mu \mathrm{l})$ was added and the wells were agitated at $37^{\circ} \mathrm{C}$ for $10 \mathrm{~min}$. Subsequently, $75 \mu \mathrm{l}$ of AAPH solution was added to each of the wells to initiate the reaction. The total volume of each reaction solution was $295 \mu$ l. The fluorescence intensity [485 nm (excitation)/535 nm (emission)] was then measured every $2 \mathrm{~min}$ over $90 \mathrm{~min}$ at $\mathrm{pH} 7.4$ and $37^{\circ} \mathrm{C}$. As the reaction progressed, fluorescein was consumed and the fluorescence intensity was decreased. The inhibition of fluorescence decay was considered to indicate the presence of an antioxidant.

Typical ORAC assay kinetic curves in the presence of various concentrations of trolox were determined. ORAC values were then measured. The area under the kinetic curve (AUC) of the standards and samples was calculated as follows: AUC $=\left(0.5+\mathrm{f}_{10 \mathrm{~min}} / \mathrm{f}_{8 \text { min }}+\mathrm{f}_{12 \mathrm{~min}} / \mathrm{f}_{8 \mathrm{~min}}+\mathrm{f}_{14 \mathrm{~min}} / \mathrm{f}_{8 \text { min }}+\ldots+\mathrm{f}_{90 \mathrm{~min}} / \mathrm{f}_{8 \mathrm{~min}}\right) \times 2$, where $f_{x \min }$ is the fluorescence reading at cycle $x \min (23)$.

The standard regression line was obtained by plotting the trolox concentrations against the net $\mathrm{AUC}_{\text {trolox }}$ of each concentration:

$$
\begin{aligned}
\text { Net } \mathrm{AUC}_{\text {trolox }} & =\mathrm{AUC}_{\text {trolox }}-\mathrm{AUC}_{\text {control }} \\
\text { Net } \mathrm{AUC}_{\text {sample }} & =\mathrm{AUC}_{\text {sample }}-\mathrm{AUC}_{\text {control }}
\end{aligned}
$$

where $\mathrm{AUC}_{\text {trolox }}$ is the $\mathrm{AUC}$ in the presence of trolox; $\mathrm{AUC}_{\text {control }}$ is the AUC with blank control and $\mathrm{AUC}_{\text {sample }}$ is the AUC with sample buffer. The horizontal axis is the net $\mathrm{AUC}_{\text {trolox }}$ and the vertical axis is the concentration of trolox. The equation $\mathrm{Y}=\mathrm{ax}+\mathrm{b}$ was derived from the above data and the values for $a$ and $b$ were obtained.

The final ORAC values of the samples were calculated using the equation: ORAC value $(\mu \mathrm{mol}$ trolox equivalent $/ 100 \mathrm{~g})=$ [a x (net $\left.\mathrm{AUC}_{\text {sample }}\right)$ x $100 /[$ sample], where [sample] is the diluted concentration ratio of the sample. Data were analyzed using Microsoft Excel.

\section{Results and Discussion}

Yaguchi et al measured the polyphenol content of JBO (A. fistulosum, used as control) and a complete set of JBO-shallot monosomic addition lines $(\mathrm{FF}+1 \mathrm{~A}$ to $\mathrm{FF}+8 \mathrm{~A})$, between January, 2002 and December, 2003 (10). They reported an 


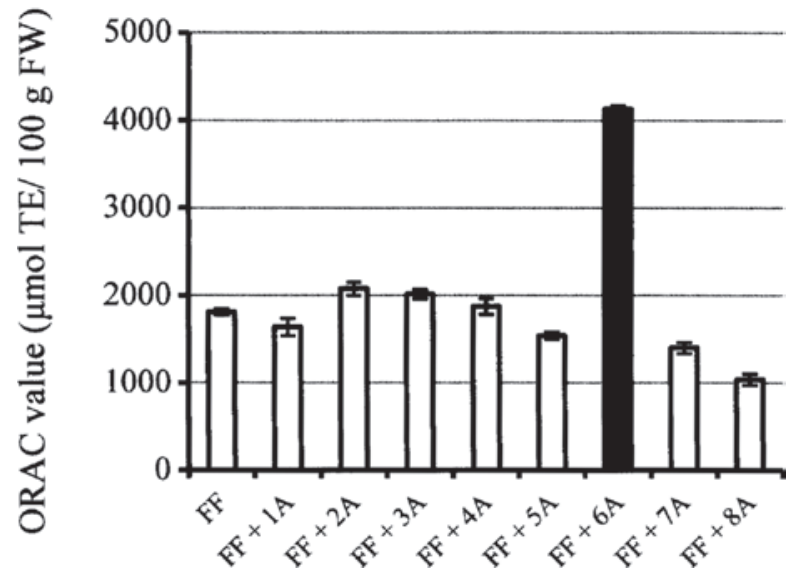

Figure 1. Hydrophilic-oxygen radical absorbance capacity (H-ORAC) values [ $\mu$ mol trolox equivalent (TE)/100 g fresh weight (FW)] representing the peroxyl radical elimination capacity of the Japanese bunching onion as the control (FF) and eight different alien monosomic addition lines $(\mathrm{FF}+1 \mathrm{~A}$ to $\mathrm{FF}+8 \mathrm{~A})$ harvested on January, $2006(\mathrm{n}=3)$.

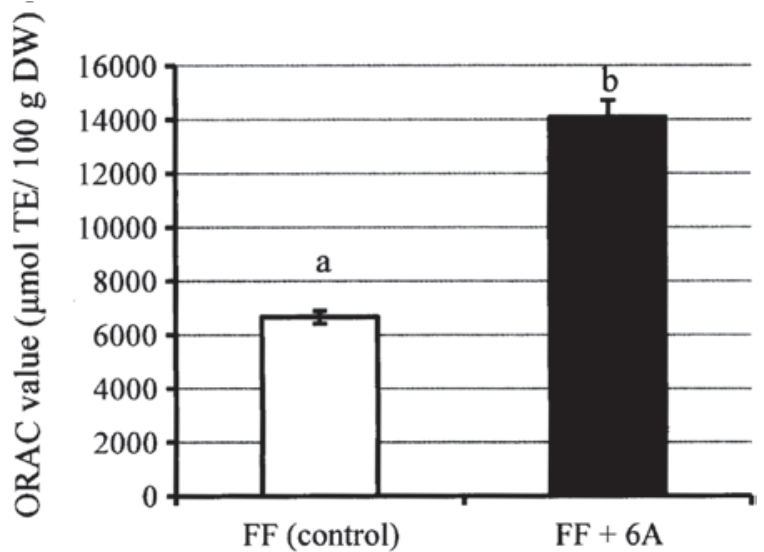

Figure 2. Hydrophilic-oxygen radical absorbance capacity (H-ORAC) values [ $\mu$ mol trolox equivalent (TE)/100 $\mathrm{g}$ fresh weight $(\mathrm{FW})]$ of the powder of the Japanese bunching onion (control) and an alien monosomic addition line $(\mathrm{FF}+6 \mathrm{~A})$ harvested on January, $2010(\mathrm{n}=3) .{ }^{\mathrm{a}, \mathrm{b}} \mathrm{P}<0.01$ represents a statistically significant difference.

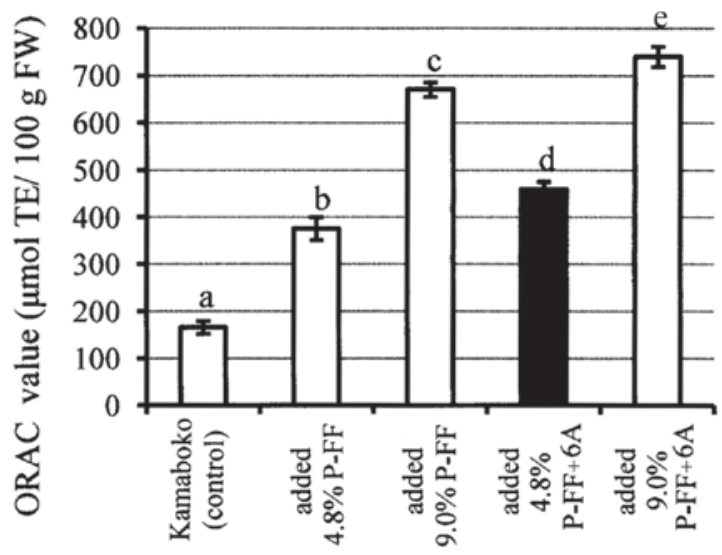

Figure 3. Hydrophilic-oxygen radical absorbance capacity (H-ORAC) values [ $\mu$ mol trolox equivalent (TE)/100 g fresh weight (FW)] of Kamaboko (control), Kamaboko containing 4.8\% P-FF (Japanese bunching onion powder), Kamaboko containing 9.0\% P-FF, Kamaboko containing 4.8\% P-FF+6A ( $\mathrm{FF}+6 \mathrm{~A}$ powder) and Kamaboko containing 9.0\% $\mathrm{P}-\mathrm{FF}+6 \mathrm{~A}(\mathrm{n}=3)$. ${ }^{\mathrm{a}-\mathrm{P}} \mathrm{P}<0.05$ represents a statistically significant difference.

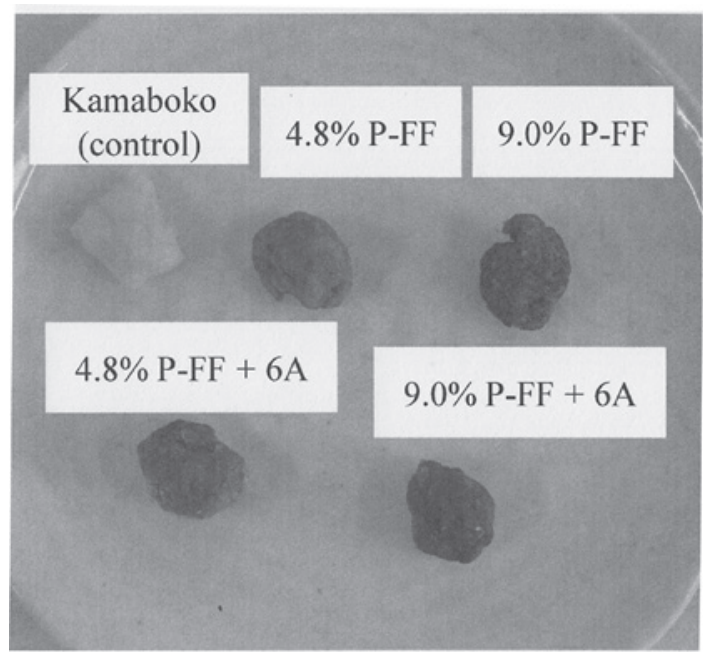

Figure 4. Pieces of Kamaboko trial products supplemented with Japanese bunching onion $(\mathrm{P}-\mathrm{FF})$ or alien monosomic addition line $(\mathrm{P}-\mathrm{FF}+6 \mathrm{~A})$.

increase in the polyphenol content of four monosomic additions, i.e., $\mathrm{FF}+2 \mathrm{~A}, \mathrm{FF}+5 \mathrm{~A}, \mathrm{FF}+6 \mathrm{~A}$ and $\mathrm{FF}+8 \mathrm{~A}$, compared to control JBO: the polyphenol content of JBO (control) was an average of $56.7 \mathrm{mg} / 100 \mathrm{~g} \mathrm{FW}$ and the content of FF+6A was an average of $83.1 \mathrm{mg} / 100 \mathrm{~g} \mathrm{FW}$. The $6 \mathrm{~A}$ chromosome of the shallot may encode a polyphenol accumulation function in the gene. Furthermore, they reported the production of L-ascorbic acid (vitamin $\mathrm{C}$ ) in $\mathrm{FF}+1 \mathrm{~A}, \mathrm{FF}+2 \mathrm{~A}$ and $\mathrm{FF}+8 \mathrm{~A}$ (24). It was also reported that a significantly higher non-reducing sugar accumulation, including sucrose, was observed in FF+8A and a significant decrease of non-reducing sugar was noted in FF+2A (25,26). The antioxidant activities, i.e., ORAC values, of the eight different monosomic additions ( $\mathrm{FF}+1 \mathrm{~A}$ to $\mathrm{FF}+8 \mathrm{~A})$ harvested on January, 2006, are presented in Fig. 1. The $\mathrm{H}-\mathrm{ORAC}$ value, representing the peroxyl radical elimination capacity of JBO harvested on January, 2006 as control, was $1,810 \pm 32 \mu \mathrm{mol} \mathrm{TE} / 100 \mathrm{~g} \mathrm{FW}$ and that of FF+6A harvested at the same time was $4,131 \pm 43 \mu \mathrm{mol}$ TE/100 $\mathrm{g} \mathrm{FW}$. The ORAC value of Kamaboko including the eight raw monosomic additions $(\mathrm{FF}+1 \mathrm{~A}$ to $\mathrm{FF}+8 \mathrm{~A})$ was measured. However, we did not obtain the expected results, i.e., Kamaboko with a high antioxidant activity (data not shown). It was hypothesized that deactivation of the antioxidant components may occur by steaming at $90^{\circ} \mathrm{C}$ for $60 \mathrm{~min}$ during the manufacturing process.

Therefore, we attempted to create two types of powders of JBO and FF+6A by freeze-drying, to avert deactivation of the antioxidant components in the samples by heated fluid. The H-ORAC value of the powder of JBO harvested on January, 2010 (control) was 6,659 $\pm 238 \mu \mathrm{mol}$ TE/100 g DW and that of FF+6A harvested at the same time was $14,096 \pm 635 \mu \mathrm{mol}$ TE/100 g DW (Fig. 2). The ORAC value of the control powder was 23.7 -times that of raw JBO and the ORAC value of the $\mathrm{FF}+6 \mathrm{~A}$ powder was 3.4-times that of raw FF+6A.

We then attempted to create Kamaboko supplemented with $\mathrm{JBO}$ or $\mathrm{FF}+6 \mathrm{~A}$ powder. As shown in Fig. 3, the ORAC values were as follows: plain Kamaboko (control), $166 \pm 14 \mu \mathrm{mol}$ TE/100 g FW; Kamaboko containing $4.8 \%$ P-FF (JBO powder), 376 $\pm 24 \mu \mathrm{mol} \mathrm{TE} / 100 \mathrm{~g} \mathrm{FW}$; Kamaboko containing $9.0 \% \mathrm{P}-\mathrm{FF}, 671 \pm 16 \mu \mathrm{mol} \mathrm{TE} / 100 \mathrm{~g} \mathrm{FW}$; 
Kamaboko containing $4.8 \% \mathrm{P}-\mathrm{FF}+6 \mathrm{~A}$ ( $\mathrm{FF}+6 \mathrm{~A}$ powder), $460 \pm 16 \mu \mathrm{mol}$ TE/100 g FW; and Kamaboko containing 9.0\% $\mathrm{P}-\mathrm{FF}+6 \mathrm{~A}, 740 \pm 21 \mu \mathrm{mol} \mathrm{TE} / 100 \mathrm{~g} \mathrm{FW}$. As demonstrated by the results, the addition of the $9.0 \% \mathrm{P}-\mathrm{FF}+6 \mathrm{~A}$ onion powder, increased the ORAC value of plain Kamaboko 4.5 -fold. These results indicated a lower value compared to the theoretical value estimated from the amount of onion powder included. This phenomenon may be attributed to deactivation of the antioxidant components of the onion powder by heating during the manufacturing process of Kamaboko $(27,28)$.

Consequently, taking into consideration the sensory evaluations of taste and appearance, as shown in Fig. 4, $4.8 \% \mathrm{P}-\mathrm{FF}+6 \mathrm{~A}$ is recommended as the best choice, since its ORAC value was $460 \mu \mathrm{mol} \mathrm{TE} / 100 \mathrm{~g} \mathrm{FW}$, which was $\sim 2.8$-times that of plain Kamaboko.

Furthermore, we aim to investigate alterations in the antioxidant activity by modification of the ingredients and the processing techniques of Kamaboko (such as steam, boil and burn) and the incorporation of other single alien chromosomes, with the aim of creating a commercial Kamaboko product with a high antioxidant activity.

\section{Acknowledgements}

The authors would like to thank Professor Tsuneo Shiba (Director of the Department of Food Science and Technology, National Fisheries University) for his insightful discussion and Mr. Masashi Fujimoto (Sanyo Foods industry, Co. Ltd.) for providing Kamaboko supplemented with onion powder.

\section{References}

1. Jafarpour A and Gorczyca EM: Alternative techniques for producing a quality surimi and kamaboko from common carp (Cyprinus carpio). J Food Sci 73: E415-E424, 2008.

2. Jafarpour A and Gorczyca EM: Characteristics of sarcoplasmic proteins and their interaction with surimi and kamaboko gel. J Food Sci 74: N16-N22, 2009

3. $\mathrm{Hu} \mathrm{Y,} \mathrm{Morioka} \mathrm{K} \mathrm{and} \mathrm{Itoh} \mathrm{Y:} \mathrm{Participation} \mathrm{of} \mathrm{cysteine}$ protease cathepsin $\mathrm{L}$ in the gel disintegration of red bulleye (Priacanthus macracanthus) surimi gel paste. J Sci Food Agric 90: 370-375, 2010.

4. Banlue $\mathrm{K}$, Morioka $\mathrm{K}$ and Itoh $\mathrm{Y}$ : Effect of $\mathrm{KBrO}_{3}$ on gel-forming properties of walleye pollack surimi through setting with or without transglutaminase inhibitor. Pak J Biol Sci 13: 1-8, 2010.

5. Jafarpour A and Gorczyca EM: Contribution of sarcoplasmic proteins to myofibrillar proteins gelation. J Food Sci 77: R73-R81, 2012.

6. Kim BY, Park JW and Yoon WB: Rheology and texture properties of surimi gels: In: Surimi and Surimi Seafood. 2nd edition. Park JW (ed). Taylor \& Francis Group, Boca Raton, pp 491-582, 2005.

7. Chan KM and Decker EA: Endogenous skeletal muscle antioxidants. Crit Rev Food Sci Nutr 34: 403-426, 1994.

8. Miyamoto Y and Nishimura K: Beneficial effects of ascorbic acid on heat-induced fish gel (Kamaboko) from the superoxide anion radical. Biosci Biotechnol Biochem 70: 480-488, 2006.

9. Ginter E and Simko V: Plant polyphenols in prevention of heart disease. Bratisl Lek Listy 113: 476-480, 2012.

10. Yaguchi S, Yamauchi N and Shigyo M: Single alien chromosome additions from shallot (Allium cepa L. Aggregatum group) increase endogenous polyphenol contents in Japanese bunching onion. J Japan Soc Hort Sci 78: 431-435, 2009.

11. Chu YH, Chang CL and Hsu HF: Flavonoid content of several vegetables and their antioxidant activity. J Sci Food Agric 80: $561-566,2000$
12. Bahorun TA, Luximon-Ramma A, Crozier A and Aruoma O Total phenol, flavonoid, proanthocyanidin and vitamin C levels and antioxidant activities of Mauritian vegetables. J Sci Food Agric 84: 1553-1561, 2004

13. Shigyo M, Tashiro Y, Isshiki S and Miyazaki S: Establishment of a series of alien monosomic addition lines of Japanese bunching onion (Allium fistulosum L.) with extra chromosomes from shallot (A. cepa L. Aggregatum group). Genes Genet Syst 71: 363-371, 1996

14. Hang TT, Shigyo M, Yamauchi N and Tashiro Y: Production and characterization of alien chromosome additions in shallot (Allium cepa L. Aggregatum group) carrying extra chromosome(s) of Japanese bunching onion (A. fistulosum L.). Genes Genet Syst 79: 263-269, 2004.

15. Masuzaki S, Shigyo M and Yamauchi N: Complete assignment of structural genes involved in flavonoid biosynthesis influencing bulb color to individual chromosomes of the shallot (Allium cepa L.). Genes Genet Syst 81: 255-263, 2006.

16. Nagatsuka N, Sato K, Harada K and Nagao K: Radical scavenging activity of 'Nikogori' gelatin gel food made from head, bone, skin, tail and scales of fishes measured using the chemiluminescence method. Int J Mol Med 20: 843-847, 2007.

17. Awatsuhara R, Harada K, Nomura T, Nikaido O and Nagao K: Alteration of antioxidative activity of rutin treated with food protein. J Clin Biochem Nutr 43 (Suppl 1): 512-515, 2008.

18. Harada K, Makino Y, Yamauchi T, et al: Efficacy of puffer fish (Takifugu rubripes) sauce in reducing hydroxyl radical damage to DNA assessed using the apurinic/apyrimidinic site method. Int J Mol Med 20: 309-314, 2007.

19. Harada K, Maeda T, Hasegawa Y, Tokunaga T, Tamura Y and Koizumi T: Antioxidant activity of fish sauces including puffer (Lagocephalus wheeleri) fish sauce measured by the oxygen radical absorbance capacity method. Mol Med Rep 3: 663-668, 2010.

20. Harada K, Maeda T, Hasegawa Y, et al: Antioxidant activity of the giant jellyfish Nemopilema nomurai measured by the oxygen radical absorbance capacity and hydroxyl radical averting capacity methods. Mol Med Rep 4: 919-922, 2011.

21. Wu X, Beecher GR, Holden JM, Haytowitz DB, Gebhardt SE and Prior RL: Lipophillic and hydrophilic antioxidant capacities of common foods in the United States. J Agric Food Chem 52: 4026-4037, 2004.

22. Ou B, Hampsch-Woodill M and Prior RL: Development and validation of an improved oxygen radical absorbance capacity assay using fluorescein as the fluorescent probe. J Agric Food Chem 49: 4619-4626, 2001.

23. Huang D, Ou B, Hampsch-Woodill M, Flanagan JA and Prior RL: High-throughput assay of oxygen radical absorbance capacity (ORAC) using a multichannel liquid handling system coupled with a microplate fluorescence reader in 96-well format. J Agric Food Chem 50: 4437-4444, 2002.

24. Yaguchi S, Atarashi M, Iwai M, Masuzaki S, Yamauchi N and Shigyo M: Production of alien addition lines in polyploid bunching onion (Allium fistulosum) carrying 1A chromosome(s) of shallot (Allium cepa) and their application breeding for a new vitamin C-rich vegetable. J Amer Soc Hort Sci 133: 367-373.

25. Hang TT, Shigyo M, Yaguchi S, Yamauchi N and Tashiro Y: Effect of single alien chromosome from shallot (Allium cepa $\mathrm{L}$. Aggregatum group) on carbohydrate production in leaf blade of bunching onion (A. fistulosum L.). Genes Genet Syst 79: 345-350, 2004.

26. Yaguchi S, McCallum J, Shaw M, et al: Biochemical and genetic analysis of carbohydrate accumulation in Allium cepa L. Plant Cell Physiol 49: 730-739, 2008.

27. Gazzani G, Papetti A, Massolini G and Daglia M: Anti- and prooxidant activity of water soluble components of some common diet vegetables and the effect of thermal treatment. J Agric Food Chem 46: 4118-4122, 1998.

28. Aoyama S and Yamamoto Y: Antioxidative activity of red Welsh onion and the effect of a thermal treatment. J Cookery Sci Jpn 39: 283-288, 2006 (In Japanese). 